\title{
YOUNG GENERATION AND ENVIRONMENTAL FRIENDLY AWARENESS: DOES IT THE IMPACT OF GREEN ADVERTISING?
}

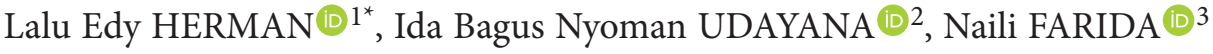 \\ ${ }^{1}$ Faculty of Business \& Economic, University of Mataram, Lombok, Indonesia \\ ${ }^{2}$ Management Department, Sarjanawiyata Tamansiswa University, Yogyakarta, Indonesia \\ ${ }^{3}$ Faculty of Business \& Economic, Diponegoro University, Semarang, Central Java, Indonesia
}

Received 6 April 2020; accepted 10 May 2020

\begin{abstract}
The environmental issues nowadays have make consumers becoming more selective in selecting products and brands going to use. The purpose of this study is to investigate the effect of green advertising on green purchase intentions mediated by green attitude awareness in the young generation. Young generation has strong curiosity and has easier access on getting products information, so this research focuses deeper on examining how much green advertising, green knowledge, and eco-label information affect the awareness on green attitude which later influences green intention to purchase. This research used primary data obtained from questionnaires distributed directly to 150 undergraduate students of universities in Indonesia. We used Structural Equation Modeling (SEM) for verifying hypothesis and AMOS 20 software for getting empirical results of 16 items questions representing indicator of 4 variables. The result showed that green advertising and green knowledge were able to form the awareness on environmental friendly. Although eco-label information did not influence the awareness on green attitude, it influenced the green purchase intention directly.
\end{abstract}

Keywords: environmental friendly, green advertising, green knowledge, green attitude, green purchase intention.

JEL Classification: D64, M31, O31, D11, K32.

\section{Introduction}

Raising the awareness on environmental friendly of consumers is not easy, although the campaign has been done for decades. The result of Ministry of Environment and Forestry in 2012 showed that environmental care attitude index (IPPL) was about 0.57 (from 1). It indicates that Indonesian do not show enough care about environment in their daily lives. Young generation is agents of changes who initiate the indifference of issues about environment and business which nowadays both have strong relationship with each other. This research is commenced from the controversy of previous study results on the effect of advertising on the purchasing intention. D'Souza and Taghian (2005) argued that advertisement is a strong tool to inform and get consumers' attitude, and critical role in communicating the pro-environmental image (Grillo et al., 2008; Kim et al., 2019), and that it has the biggest effect on the purchase intention (Delafrooz et al., 2014). On contrary, Rahbar and Wahid (2011) found that there was not any significant relationship between green advertising and the purchase intention.
Consumers coming from young generation group of age have high idealism, bravery, and open for new values and ideas, and obviously they are innovative with high creativities. They should be more perceptive and aware to the phenomenon where there are many effects of environmental damages such as global warming that causes natural disasters and unsuccessful harvests because of extreme weather change. These young consumers are important target market for products as well as social idea, and will be the future marketing planners, policy makers and the educators of the new economy (Kabaday1 et al., 2015; Sharaf et al., 2015). Green consumerism is a movement to protect global consumers began with the awareness of consumers' rights of getting proper products, edible, and eco-friendly (Sachdeva et al., 2015). The consumers' understanding on environmental issues has become a critical point on the improvement of company, even though the level of understanding is different from each other based on their knowledge.

Companies use environmental issues as business opportunity to compete in the industry. The change in market dynamics along with the change of orientation and

*Corresponding author. E-mail: edyherman@unram.ac.id 
consumers' attitude has caused the marketers to find a new way to advertise their products (D'Souza \& Taghian, 2005). The rise of consumers' awareness on environmental preservation is supported by companies by applying environmental issues as one of the market strategies that called as green marketing (Bhattacharya, 2011; Golnaz, 2012; Polonsky, 1994). Green marketing is a new focus and trend on modern business (Kassaye, 2001; Song-Turner \& Polonsky, 2016). Companies with green marketing concept try to create green products, i.e. the products are for human and environment, saving resources, and do not produce much waste, and do not involve violence on animals (Chen \& Chang, 2013).

The attention on environmental issues is marked by vigorous acts of businessmen in applying international standards as the international recognition on eco-friendly business acts. The attention looks real by looking at the increasing market numbers which are caring about environment (Haws et al., 2014). This condition makes sellers become more careful when they use market strategies related to the environmental issues. This research aims to develop a model of environmental friendly awareness on young generation and to test the effect of green advertising on green purchase intention of young generation in Indonesia as a part of developing country.

\section{Literature review \& hypothesis development}

\subsection{Green advertising}

Advertisement is one of components in promotion which can be found in the form of direct advertisement, personal selling, selling promotion, and publicity. Advertisement is a non-personal promotion using media in order to stimulate purchasing by offering products to consumers as a background to create purchasing. Green advertising focuses on the activities of companies to campaign the programs which emphasize the environmental issues to strengthen their images as eco-friendly companies (D'Souza \& Taghian, 2005; Haytko \& Matulich, 2010). Green advertising is an attempt done by the company to push consumers to buy green products they produce so the attempt costs more to fund the advertising (Kim et al., 2019; Yang et al., 2015). Yang et al. (2015) explained green advertising as an act to influence consumers' attitude by supporting consumers to buy eco-friendly products and aim their attention on positive consequences from their purchasing attitude.

Terms such as phosphate-free, recycle, refill, ozonefriendly, and eco-friendly are ones that been promoted as green advertising. The key of the success is credibility that is not exaggerating the environmental excellence of the products nor building unrealistic hopes for consumers, so the communication of environmental excellence is delivered in trustworthy characters (Kao \& Du, 2020). One of the biggest challenges today is how to promote and stimulate people to adopt the sustainable environmental friendly behavior (Delafrooz et al., 2014). Previous researches on the issue have warned the importance of using green advertising to promote green consumption attitude.

Along with the increase of green attitude in the world including the increasing of public attention on environmental issues, most of organizations have chosen green advertising through printed and electronic media as a way to introduce their products to pro-environment consumers (Rahbar \& Wahid, 2011). In order to maximize the effectiveness of green advertising, researchers and marketers have been trying to understand the relationship between consumers' attitude to advertisement and how advertisement influences purchase intention (Choi \& Johnson, 2019; Duffett, 2015). The research done by Akehurst et al. (2012) showed the result that consumers consider green advertising as a more effective way to improve their knowledge on green products and is very helpful in making decision based on the information given. That is why green advertising can help to improve the motivation to purchase green products (Choi \& Johnson, 2019; Hartmann \& Ibanez, 2006).

$\mathbf{H}_{1}$ : Green advertising awareness has a positive and significant influence on attitude awareness.

\subsection{Green knowledge}

The knowledge owned by someone will involve the change of attitude caused by experiences. Knowledge is known as a characteristic influencing all the steps in decision-making (Chen et al., 2018; Choi \& Johnson, 2019; Goh \& Balaji, 2016). Knowledge is relevant and important construction influencing how consumers gather information, how much it is used for making decision, and how consumers evaluate products and service used (Aman et al., 2012). Consumers who consider the importance of environment consequences will buy eco-friendly products (Kianpour et al., 2014). Most of consumers do not have enough knowledge on environmental issues as the background of attitude to manage the environment in full of responsible ways (Priya et al., 2010). Environmental knowledge is general knowledge on facts, concepts, and relationship of the natural environment and ecosystem (Fryxell \& Lo, 2003).

The higher knowledge owned by consumers on environment will cause better pro-environment attitude (Rokicka, 2002; Suki, 2016). Higher knowledge gives positive effect on the attitude towards environment. The knowledge on environment will affect the attitude to use eco-friendly products, the higher the knowledge the better the attitude towards environment (Fryxell \& Lo, 2003; Irandust \& Naser, 2014). The awareness of consumers is formed from high responsibility on environment and respect the existence of other creatures on earth.

$\mathbf{H}_{2}$ : Green knowledge has a positive and significant influence on attitude awareness.

\subsection{Eco-labeling information}

The decreasing condition of environment causes consumers to be more sensitive on environment, preference, and purchasing pattern of products (Rashid, 2009). For the 
several last decades, environmental issues and problems have been discussed widely by people around the world. Many respondents from many countries state their worries about the environmental issues (Sachdeva et al., 2015). Consumers are getting more aware on the seriousness of environment degradation leading to higher ecological awareness and more will to buy eco-friendly products, and support on eco-friendly business (Biswas, 2016; Jaiswal \& Kant, 2018; Ng \& Law, 2015).

The issues on products and environment are announced by many companies but the obstruction comes from consumers who have little knowledge on the things included to eco-friendly claim. The main guide for consumers is limited on the information given by companies through advertising. One of the forms of responsibility is by giving information on eco-friendly products on the label of the products. Eco-label is more frequently used by marketers to identify the green products (D'Souza et al., 2006). Hosseinikhah Choshaly (2019) defined eco-label as a mean to help consumers to decide to buy green products and to inform them how the product was made.

The information of eco-label on a product is not only useful for consumers but also for companies who claim themselves as eco-friendly. For consumers, the advantage of this eco-label application is they can get information on the effect of the product on environment, while for companies it is a weapon to enter the market and get market share (D'Souza et al., 2006). The awareness on eco label has positive relationship with knowledge on eco-label and consumers purchase attitude (Rashid, 2009). In other study done by Teisl et al. (2002) found that consumers who give positive responses on eco-label will increase market share of the product. The information given by eco-label is proven to influence consumers' preferences on a product, especially if the consumers have high awareness on environment (Grankvist et al., 2004).

$\mathbf{H}_{3}$ : Eco-labeling information has a positive and significant influence on attitude awareness.

$\mathbf{H}_{\mathbf{4}}$ : Eco-labeling information has a positive and significant influence on purchase intention.

\subsection{Purchase intention}

Intention depends on habit of planning and purchasing a product or service including the will to pay higher price for the products. Purchase intention is situation happens before someone doing an action used as the base of predicting action (Ajzen \& Fishbein, 2001; Suki, 2016); the plan of an individual to do purchasing effort (Spears \& Singh, 2004); physical activity which occurs because of the feelings and thoughts on the desired products (Schiffman \& Kanuk, 2007).

The purchase intention is often used to analyze consumers' attitude. Before purchasing, consumers will usually gather some information on the products based on personal experiences and information from society. Schiffman and Kanuk (2007) stated that motivation is the one from inside that pushes consumers to take action. If someone has high motivation on a product, they will be motivated to take action on getting the product. On contrary, if the motivation is low, they will try to keep out of the product. Mostafa (2009) found that environmental knowledge has significant effect on consumers' intention to buy green products. The result from Mei et al. (2012) showed the environmental knowledge affects the purchase intention on eco-friendly products of Malaysian consumers.

$\mathbf{H}_{5}$ : Green knowledge has a positive and significant influence on purchase intention.

\subsection{Green attitudes}

Attitude can be defined as feeling and evaluation of potential tendency to act which is a result of interaction between cognitive, affective, and conative that reacting with each other to understand, feel, and behave to an object. Green attitude awareness is identified as individual attitude related to promotion and environment preservation. The awareness rises from consumers' selfconcept and how deep he feels himself to be integrated part of nature (Patrick et al., 2005). The attitude of a consumer represents whether or not the consumer likes it (Suki, 2016).

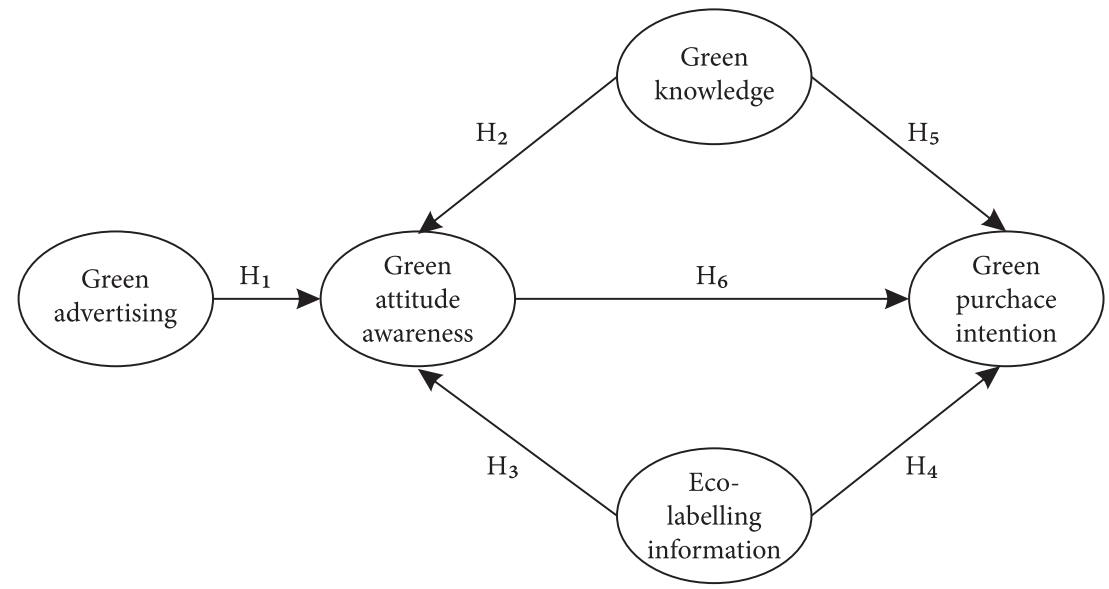

Figure 1. The model of consumer attitude awareness drive on green product 
Consumers' level of trust is a result from knowledge development of consumers. Consumers' belief and attitude was the two essential factors affect their intention to use green product (Choi \& Johnson, 2019). The attitude will affect purchase intention on eco-friendly products, based on research done by Aman et al. (2012); Irandust and Naser (2014), which proved that attitudes give positive effect on purchase intention on eco-friendly products.

$\mathbf{H}_{6}$ : Green attitude awareness has a positive and significant influence on purchase intention.

\section{Empirical model}

Based on the literature review, we propose a research model showing in Figure 1. Figure 1 shows the relationship between the variable influences of green advertising on green purchase intention mediated by green attitude awareness. Green knowledge and eco-labeling information variables strengthen the model in the mediating variable green attitude awareness on green purchase intention.

\section{Research method}

\subsection{Population and sampling}

This research was done in some universities in Indonesia with all undergraduate students as young consumers. The sampling method was non-probability sampling with convenience sampling. In convenience sampling, respondents were selected randomly without any specific criteria that must be filled of becoming the sample (Cooper \& Emory, 1995; Hertwig \& Pleskac, 2010). The minimum number of samples in SEM model must be 5 times of the number of indicator variables used (Hair et al., 2010). In this research, the number of indicator variables was 20 , hence, the minimum number of samples to meet the sample adequacy assumption is 100. Based on this consideration, the samples used in this research were 150 respondents and fulfilled the condition of sample adequacy.

\subsection{Research instrument and measurement}

The questionnaires or list of questions consisted of 16 items representing dependent variables and 4 items representing independent variables. The questionnaires were distributed directly so the respondents could give scores and short answers to the open questions given. The questionnaires were designed by using 10 points Likert scale started from 1 = Strongly Disagree to $10=$ Strongly Agree.

\subsection{Validity and instruments reliability test}

Validity depicts how accurate and precise a measuring tool in doing its functions. The validity was tested using Confirmatory Factor Analysis (CFA) with software SPSS 16.0 for Windows. Before analysis factor test, Kaiser Meyer Olkin (KMO) test and Bartlett's Test were done to test the correlation among the variables. The higher the KMO result of each question, the more homogeneous

Table 1 . Validity and reliability testing results

\begin{tabular}{|c|c|c|c|c|}
\hline \multicolumn{2}{|l|}{ Variables } & Indicators & $\begin{array}{l}\text { Factor } \\
\text { Loading }\end{array}$ & $\begin{array}{c}\text { Cronbach's } \\
\text { alpha }\end{array}$ \\
\hline \multirow{4}{*}{$\begin{array}{l}\text { Green } \\
\text { Advertising }\end{array}$} & GA1 & Reminder on environmental friendly issue & 0.946 & 0.924 \\
\hline & GA2 & The environmentally friendly product message conveyed clearly & 0.943 & \\
\hline & GA3 & Green product design creativity & 0.931 & \\
\hline & GA4 & The environment friendly slogan attractiveness & 0.911 & \\
\hline \multirow{4}{*}{$\begin{array}{l}\text { Eco-labeling } \\
\text { Information }\end{array}$} & ELI1 & The environmental friendly symbols informativeness & 0.789 & 0.842 \\
\hline & ELI2 & The statement contained in the label of products & 0.827 & \\
\hline & ELI3 & The explanation of environmentally friendly products composition & 0.783 & \\
\hline & ELI4 & Explanation of dangerous compound for the environment effect & 0.632 & \\
\hline \multirow{4}{*}{ Green Knowledge } & GK1 & The balance of nature is very delicate & 0.927 & 0.960 \\
\hline & GK2 & Humans are seriously harming the environment & 0.909 & \\
\hline & GK3 & know that green products contribute to the sustainable future & 0.928 & \\
\hline & GK4 & Know about recycling, reuse and reduce & 0.937 & \\
\hline \multirow{4}{*}{$\begin{array}{l}\text { Green Attitude } \\
\text { Awareness }\end{array}$} & GAA1 & Know to select products and packages that reduce the amount of waste & 0.972 & 0.977 \\
\hline & GAA2 & Have a tendency to switch to another brand for buying green product & 0.968 & \\
\hline & GAA3 & Will adopt a green lifestyle & 0.952 & \\
\hline & GAA4 & To be more socially responsible & 0.931 & \\
\hline \multirow{4}{*}{$\begin{array}{l}\text { Green Purchase } \\
\text { Intention }\end{array}$} & GPI1 & Have a tendency to purchase green products & 0.947 & 0.968 \\
\hline & GPI2 & Have plans to buy green products in the future & 0.969 & \\
\hline & GPI3 & Will buy the green products than non-green products & 0.929 & \\
\hline & GPI4 & Possibility to buy green products is very high & 0.914 & \\
\hline
\end{tabular}


the variables are. The score of KMA-MSA must be above 0.5 with significance $<0.05$ so the variables are predictable and can be analyzed further (Hair et al., 2010). The result of KMO-MSA in this research was 0.704 with significance of 0.000 . The validity of the instruments is determined by factor loading value. Hair et al. (2010) stated that the acceptable value of factor loading is $\geq$ 0.40 and it is not a part of other factors. Based on validity test, all the instruments used in this research had factor loading score at above 0.40 and was not a part of other factors.

Reliability test is used for measuring the persistence of research instruments. Reliability in this research was measured with Cronbach's Alpha coefficient. The acceptable value is $\geq 0.7$ although 0.6 can be considered as acceptable (Hair et al., 2010). Based on validity and reliability test in this research, all instruments had Cronbach's Alpha more than 0.7. So the instruments could be concluded as reliable. Table 1 shows the result from research instruments validity test in this study.

\section{Data analysis}

\subsection{Fit model assessment}

The result of structural equation fit model assessment is shown in Figure 2.

Figure 2 is the result of structural equation fit model assessment showing that the model has fulfilled the criteria of fit model showed by GFI value of 0.872 and AGFI value of 0.833 in which the numbers are close to the criteria which is 0.90 . Likewise, the value of TLI at 0.968 has met the criteria of above 0.95 and RMSEA value of 0.063 has fulfilled the criteria lower than 0.08 . Hence, the structural equation model was concluded as fit.

\subsection{Hypotheses test results}

We used Structural Equation Modeling (SEM) for verifying hypotheses and AMOS 20.0 software for getting empirical results. Table 2 shows the result of hypotheses test proposed in this research.

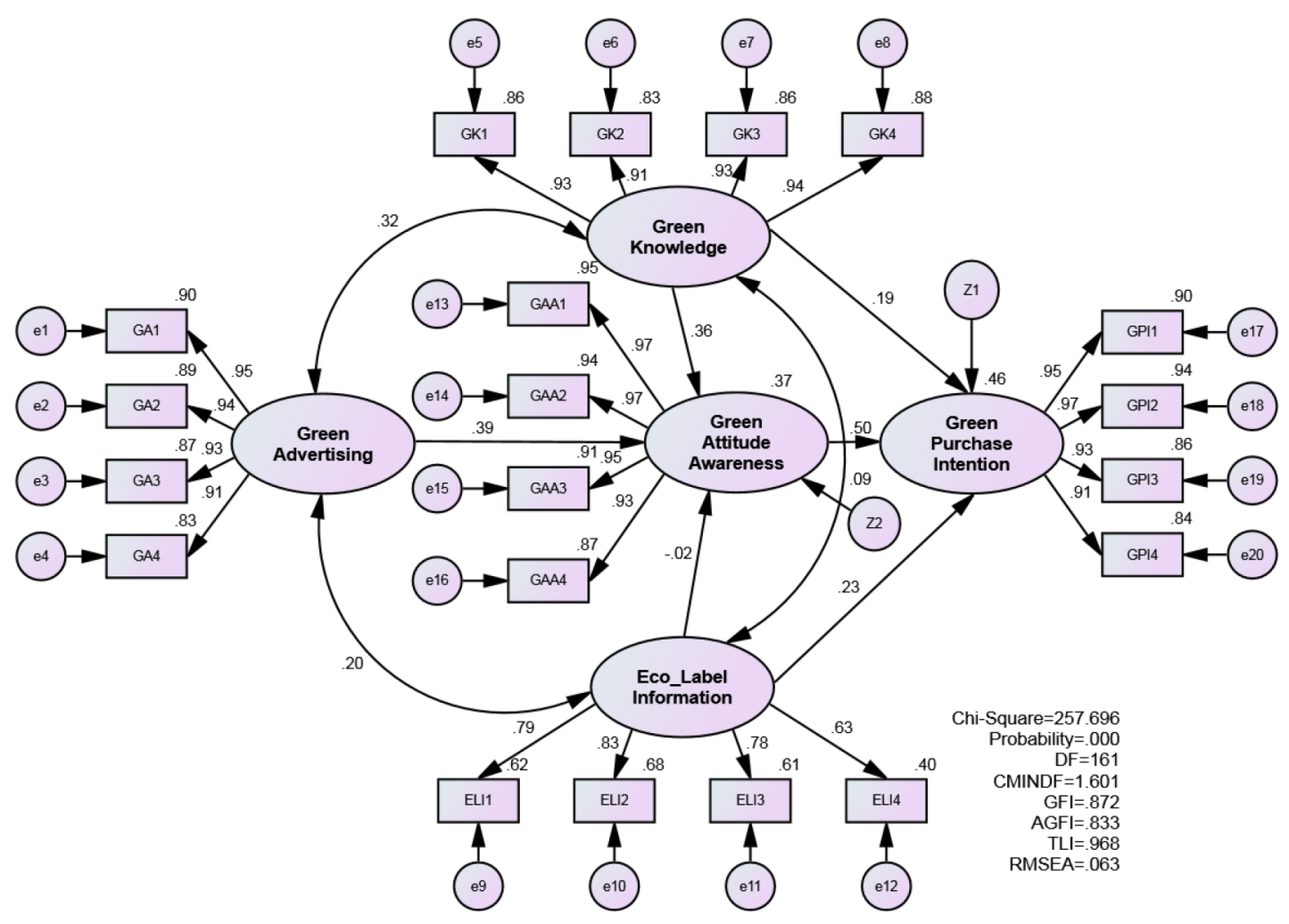

Figure 2. Full model structural

Table 2. Standardized path coefficients for the structural model

\begin{tabular}{|l|l|l|c|c|l|l|}
\hline \multicolumn{2}{|c|}{ Construct } & Estimate & S.E. & C.R. & \multicolumn{1}{|c|}{ Hypotheses Test } \\
\hline Green_Attitude_Awareness & $<---$ & Green_Advertising & .402 & .078 & 5.135 & Supported \\
\hline Green_Attitude_Awareness & $<---$ & Eco_Label_Information & -.022 & .092 & -.242 & Not Supported \\
\hline Green_Attitude_Awareness & $<---$ & Green_Knowledge & .344 & .070 & 4.890 & Supported \\
\hline Green_Purchase_Intention & $<---$ & Green_Attitude_Awareness & .544 & .083 & 6.571 & Supported \\
\hline Green_Purchase_Intention & $<---$ & Eco_Label_Information & .311 & .099 & 3.142 & Supported \\
\hline Green_Purchase_Intention & $<---$ & Green_Knowledge & .196 & .077 & 2.537 & Supported \\
\hline
\end{tabular}


There was one insignificant result that was the influence of eco-label information on green attitude awareness. Thus, $\mathrm{H} 2$ was not supported while $\mathrm{H} 1, \mathrm{H} 3, \mathrm{H} 4$ and $\mathrm{H} 5$ were supported in this research.

\section{Discussion}

The results of this research showed that; first, green advertising is the biggest potential issue to influence the green awareness on young consumers in Indonesia to choose and use green products. The result supports the previous finding stating that consumers who have higher green awareness will have better attitude on green advertising (Golnaz, 2012; Yang et al., 2015). Second, the result implied that green advertising is perhaps the best effort to reach consumers with green attitude. Green attitude awareness positively influences green products purchase intention. The research underlines the previous research done by Suki (2016) and Kim et al. (2019) arguing that green awareness has a positive influence on green products purchase intention. The positive attitude of consumers gives more guided behavior in which the strong intention of consumers must behave under their control (Ajzen \& Fishbein, 2001; Kabaday1 et al., 2015). In this study, the strong intention of young consumers in Indonesia to use green product is a positive attitude towards green advertising. While optimistic consumers respond on green advertising, companies image, and their green products. In this case, companies have to emphasize the real actions on environmental care which will lead consumers to differentiate green companies and non-green companies claiming themselves as green products producers.

Third, this research showed that consumers' green knowledge really influences the rise of green attitude awareness and directly can improve their green purchase intention. This result supports the study by Lee (2011) and Jogova et al. (2013) that educated-consumers were getting worried about the long-term effects of products on their health, society, and environment. The green knowledge must become an opportunity for companies to boost the purchase intention of young consumers through education programs, and green knowledge sharing continuously conducted. The awareness on environment is still needed by consumers to clearly know the concept of green products. The green products purchase intention is significantly higher compared to non-green approach (Borin et al., 2013; Choi \& Johnson, 2019).

Fourth, the result of this study shows that eco-labeling information does not influence green attitude awareness on young consumers but it directly increases green purchase intention. It confirms Hosseinikhah Choshaly (2019) and $\mathrm{Li}$ (2020) in that eco-labeling positively influences consumers in making decision to choose green products and informing the consumers on how the products are made.

\section{Conclusions, implications, and limitation}

\section{Conclusions}

According to the result of the study, we can conclude that systematic and organized scheme is really needed to launch green advertising campaign. The implementation of green attitudes will create positive images of the company and build competitive excellence amid competition. Second, the result revealed that environmental caring in green advertising played the most important role in influencing green products purchase intention. Because of the concerns over environmental preservation, thus, detailed information and real advantages of green products must be provided to broaden consumers' knowledge on green products. Third, consumers' green attitude awareness also positively influences green products purchase intention. In this study, the strong young Indonesian consumers' intention to use/buy green products is their positive attitude towards the use of green products and their quite highlevel of green knowledge.

\section{Implications}

This study gives several implications for green companies in Indonesia to develop and apply green marketing strategy to influence consumers to stand on green awareness and willingness to use green products as a new marketing strategy. First, companies can actively take part in strategic environment preservation by focusing on showing commitment to care about the earth and the people. They can develop the green concept through advertising as a way of communication with consumers through campaign activities on programs raising environmental issues that are able to firm their image as green companies. The promotion can be done through advertising, selling promotion, and social interaction. Second, green marketing is an important issue in industry which products cause dangerous waste and society as the consumers are getting worried about the use of green products. Green company is a long-term business strategy aiming not only profit but also sustainable environment preservation. Green marketing strategy can be done consistently by educating their consumers, strengthening company's credibility, and involving consumers in activities held by the green companies.

\section{Limitations and future research}

Limitation of this study is in the respondents, i.e. only young consumers coming from university students in one city in Indonesia with unknown population. Hence, the sample size of the study adapted might not be perfect to represent the characteristic of whole population. Future research should use respondents from some cities in Indonesia and add more variables; such as, covering subjective norms of the consumers and factors of government supports and rules in raising the green attitude awareness. 


\section{References}

Ajzen, I., \& Fishbein, M. (2001). Attitudes and the attitude-behavior relation: Reasoned and automatic processes. European Review of Social Psychology, 11(1), 1-33. https://doi.org/10.1080/14792779943000116

Akehurst, G., Afonso, C., \& Goncalves, M. H. (2012). Re-examining green purchase behaviour and the green consumer profile: new evidences. Management Decision, 50(5), 972-988. https://doi.org/10.1108/00251741211227726

Aman, A. H. L., Harun, A., \& Hussein, Z. (2012). The influence of environmental knowledge and concern on green purchase intention the role of attitude as a mediating variable. British Journal of Arts and Social Sciences, 7(2), 145-167.

Bhattacharya, S. (2011). Consumer attitude towards green marketing in India. The IUP Journal of Marketing Management, $X(4), 62-71$.

Biswas, A. (2016). A study of consumers' willingness to pay for green products. Journal of Advanced Management Science, 4(3) 211-215. https://doi.org/10.12720/joams.4.3.211-215

Borin, N., Mullikin, \& Krishnan, R. (2013). An analysis of consumer reactions to green strategies. Journal of Product \& Brand Management, 22(2), 118-128. https://doi.org/10.1108/10610421311320997

Chen, H., Tsai, F.-S., \& Ling, H.-C. (2018). Business area changes and entrepreneurial persistence in ecology- and food-related industries: knowledge heterogeneity and emotion perspectives. Sustainability, 10(4), 929.

https://doi.org/10.3390/su10040929

Chen, Y.-S., \& Chang, C.-H. (2013). The determinants of green product development performance: green dynamic capabilities, green transformational leadership, and green creativity. Journal of Business Ethics, 116, 107-119. https://doi.org/10.1007/s10551-012-1452-x

Choi, D., \& Johnson, K. K. P. (2019). Influences of environmental and hedonic motivations on intention to purchase green products: An extension of the theory of planned behavior. Sustainable Production and Consumption, 18, 145-155. https://doi.org/10.1016/j.spc.2019.02.001

Cooper, D. R., \& Emory, C. W. (1995). Bussiness research methods, 5. Richard D. Irwin, Inc.

D’Souza, C., \& Taghian, M. (2005). Green advertising effects on attitude and choice of advertising themes. Asia Pacific Journal of Marketing and Logistics, 17(3), 51-66. https://doi.org/10.1108/13555850510672386

D’Souza, C., Taghian, M., Lamb, P., \& Peretiatkos, R. (2006). Green products and corporate strategy: an empirical investigation. Society and Business Review, 1(2), 144-157. https:// doi.org/10.1108/17465680610669825

Delafrooz, N., Taleghani, M., \& Nouri, B. (2014). Effect of green marketing on consumer purchase behavior. QScience Connect, 5. https://doi.org/10.5339/connect.2014.5

Duffett, R. G. (2015). Facebook advertising's influence on intention-to-purchase and purchase amongst Millennials. Internet Research, 25(4), 498-526. https://doi.org/10.1108/IntR-01-2014-0020

Fryxell, G. E., \& Lo, C. W. H. (2003). The influence of environmental knowledge and values on managerial behaviours on behalf of the environment: an empirical examination of managers in China. Journal of Business Ethics, 46(1), 45-69. https://doi.org/10.1023/A:1024773012398

Goh, S. K., \& Balaji, M. S. (2016). Linking green skepticism to green purchase behavior. Journal of Cleaner Production, 131, 629-638. https://doi.org/10.1016/j.jclepro.2016.04.122
Golnaz, R. (2012). Consumers' awareness and consumption intention towards green foods. African Journal of Business Management, 6(12). https://doi.org/10.5897/AJBM11.1414

Grankvist, G., Dahlstrand, U., \& Biel, A. (2004). The Impact of environmental labelling on consumer preference: negative vs positive labels. Journal of Consumer Policy, 27(2), 213-230. https://doi.org/10.1023/B:COPO.0000028167.54739.94

Grillo, N., Tokarczyk, J., \& Hansen, E. (2008). Green advertising developments in the US forest sector: a follow up. Forest Products Journal, 58(5), 40-56.

Hair, J. F., Black, W. C., Babin, B. J., \& Anderson, R. E. (2010). Multivariate data analysis (7 ed.). Prentice Hall.

Hartmann, P., \& Ibanez, A. V. (2006). View point: green value added. Marketing Intelligence \& Planning, 24(7), 673-680. https://doi.org/10.1108/02634500610711842

Haws, K. L., Winterich, K. P., \& Naylor, R. W. (2014). Seeing the world through GREEN-tinted glasses: Green consumption values and responses to environmentally friendly products. Journal of Consumer Psychology, 24(3), 336-354. https://doi.org/10.1016/j.jcps.2013.11.002

Haytko, D. L., \& Matulich, E. (2010). Green advertising and environmentally responsible consumer behaviors: linkages examined. Journal of Management and Marketing Research, 1, 1-8.

Hertwig, R., \& Pleskac, T. J. (2010). Decisions from experience: why small samples? Cognition, 115(2), 225-237. https://doi.org/10.1016/j.cognition.2009.12.009

Hosseinikhah Choshaly, S. (2019). Applying innovation attributes to predict purchase intention for the eco-labeled products. International Journal of Innovation Science, 11(4), 583-599. https://doi.org/10.1108/IJIS-04-2019-0038

Irandust, M., \& Naser, B. (2014). The role of customer's believability and attitude in green purchase intention. Arabian Journal of Bussiness and Management Review, 3(7), 242-248. https://doi.org/10.12816/0018301

Jaiswal, D., \& Kant, R. (2018). Green purchasing behaviour: A conceptual framework and empirical investigation of Indian consumers. Journal of Retailing and Consumer Services, 41, 60-69. https://doi.org/10.1016/j.jretconser.2017.11.008

Jogova, M., Song, J. E., Campbell, A. C., Warbuton, D., Warshawski, T., \& Chanoine, J. P. (2013). Process evaluation of the Living Green, Healthy and Thrifty (LiGHT) web-based child obesity management program: combining health promotion with ecology and economy. Canadian Journal of Diabetes, 37(2), 72-81. https://doi.org/10.1016/j.jcjd.2013.03.359

Kabadayı, E. T., Dursun, İ., Alan, A. K., \& Tuğer, A. T. (2015). Green purchase intention of young Turkish consumers: effects of consumer's guilt, self-monitoring and perceived consumer effectiveness. Procedia - Social and Behavioral Sciences, 207, 165-174. https://doi.org/10.1016/j.sbspro.2015.10.167

Kao, T.-F., \& Du, Y.-Z. (2020). A study on the influence of green advertising design and environmental emotion on advertising effect. Journal of Cleaner Production, 242, 118294. https://doi.org/10.1016/j.jclepro.2019.118294

Kassaye, W. W. (2001). Green dilemma. Marketing Intelligence \& Planning, 19(6), 444-455. https://doi.org/10.1108/EUM0000000006112

Kianpour, K., Anvari, R., Jusoh, A., \& Fauzi Othman, M. (2014). Important motivators for buying green products. Intangible Capital, 10(5). https://doi.org/10.3926/ic.470

Kim, W.-H., Malek, K., \& Roberts, K. R. (2019). The effectiveness of green advertising in the convention industry: An application of a dual coding approach and the norm activation model. Journal of Hospitality and Tourism Management, 39, 185-192. https://doi.org/10.1016/j.jhtm.2019.04.007 
Lee, K. (2011). The green purchase behavior of Hong Kong young consumers: the role of peer influence, local environmental involvement, and concrete environmental knowledge. Journal of International Consumer, 23, 21-44. https://doi.org/10.1080/08961530.2011.524575

Li, Y. (2020). Competing eco-labels and product market competition. Resource and Energy Economics, 60, 101149. https://doi.org/10.1016/j.reseneeco.2020.101149

Mei, O. J., Ling, K. C., \& Piew, T. H. (2012). The antecedents of green purchase intention among Malaysian consumers. Asian Social Science, 8(13), 248-263. https://doi.org/10.5539/ass.v8n13p248

Mostafa, M. (2009). Shades of green. A psychographic segmentation of the green consumer in Kuwait using self-organizing maps. Expert Systems with Applications, 36(8), 11030-11038. https://doi.org/10.1016/j.eswa.2009.02.088

Ng, M., \& Law, M. (2015). Encouraging green purchase behaviours of Hong Kong consumers. Asian Journal of Business Research, 5(2). https://doi.org/10.14707/ajbr.150013

Patrick, H., Ibanez, V. A., \& Sainz, F. J. F. (2005). Green branding effects on attitude: functional vs emotional positioning strategies. Marketing Intelligence and Planning, 23(1), 9-30. https://doi.org/10.1108/02634500510577447

Polonsky, M. J. (1994). An Introduction to green marketing. Electronic Green Journal, 1(2). https://doi.org/10.5070/G31210177

Priya, P., Baisya, R. K., \& Sharma, S. (2010). Television advertisements and children's buying behaviour. Marketing Intelligence \& Planning, 28(2), 151-169. https://doi.org/10.1108/02634501011029664

Rahbar, E., \& Wahid, N. A. (2011). Investigation of green marketing tools' effect on consumers' purchase behavior. Business Strategy Series, 12(2), 73-83. https://doi.org/10.1108/17515631111114877

Rashid, N. A. (2009). Awareness of eco-label in Malaysia's green marketing initiative. International Journal of Business and Management, 4(8), 132-141.

https://doi.org/10.5539/ijbm.v4n8p132
Rokicka, E. (2002). Attitudes toward natural environment. International Journal of Sociology, 32, 78-90. https://doi.org/10.1080/15579336.2002.11770256

Sachdeva, S., Jordan, J., \& Mazar, N. (2015). Green consumerism: moral motivations to a sustainable future. Current Opinion in Psychology, 6, 60-65. https://doi.org/10.1016/j.copsyc.2015.03.029

Schiffman, L. G., \& Kanuk, L. L. (2007). Consumer behavior (9th ed.). Prentice Hall.

Sharaf, M. A., Isa, F. M., \& Al-Qasa, K. (2015). Young consumers' intention towards future green purchasing in Malaysia. Journal of Management Research, 7(2), 468. https://doi.org/10.5296/jmr.v7i2.6998

Song-Turner, H., \& Polonsky, M. (2016). Enviropreneurial marketing in greening corporate activities. European Business Review, 28(5), 506-531. https://doi.org/10.1108/EBR-12-2014-0087

Spears, N., \& Singh, S. N. (2004). Measuring attitude toward the brand and purchase intentions. Journal of Current Issues \& Research in Advertising, 26(2). https://doi.org/10.1080/10641734.2004.10505164

Suki, N. M. (2016). Green product purchase intention: impact of green brands, attitude, and knowledge. British Food Journal, 118(12), 2893-2910. https://doi.org/10.1108/BFJ-06-2016-0295

Teisl, M. F., Roe, B., \& Hicks, R. (2002). Can eco-labels tune a market? Evidence from Dolphin-Safe Labeling. Journal of Environmental Economics and Management, 43(3), 339-359. https://doi.org/10.1006/jeem.2000.1186

Yang, D., Lu, Y., Zhu, W., \& Su, C. (2015). Going green: How different advertising appeals impact green consumption behavior. Journal of Business Research 68(12), 2663-2675. https://doi.org/10.1016/j.jbusres.2015.04.004 